SPECIAL THEME

Conscription as Military Labour:

The Middle East Experience 
International Review of Social History 43 (1998), pp. 405-419

(C) 1998 Internationaal Instituut voor Sociale Geschiedenis

\title{
Conscription as Military Labour: The Historical Context ${ }^{\mathrm{T}}$
}

\author{
JAN LuCASSEN AND ERIK JAN ZÜRCHER
}

For most of the nineteenth and twentieth century, universal conscription has been by far the predominant system of military recruitment, but the phenomenon has received surprisingly little attention from social historians. ${ }^{2}$ This lack of attention is all the more surprising if one considers the interesting position occupied by conscription at the crossroads of wage and nonwage labour and free and unfree labour.

The following articles by Khaled Fahmy, Erik Jan Zürcher and Stephanie Cronin deal with the spread of the conscription system in one specific area (the Middle East) where it has been the most prominent feature of the establishment of increased and centralized state control over societies which, until relatively recent times, consisted of largely self-sufficient agrarian communities with very little contact with the outside world. The introduction of universal conscription confronted both states and populations with entirely new demands and problems.

In order to understand the specific characteristics of the system, a comparative approach is necessary, placing it in the context of two repertoires: that of the options facing states in search of military resources and that of the options open to individuals, communities and entire societies defending their interests in the face of the demands made by the state. Conscription, after all, is only one form of recruitment of soldiers, feasible and desirable only under a specific set of conditions, so to be understood it has to be studied within the framework of military recruitment through the ages.

In adopting this comparative approach, we aim to draw attention to the similarities between the developments in Europe and in the Middle East, thus bringing out the dynamics inherent in different systems and, inciden-

I. The articles by Khaled Fahmy, Erik Jan Zürcher and Stephanie Cronin were presented as papers during a symposium organized jointly by the International Institute of Social History and the Middle East Institute of the University of Nijmegen, on the occasion of the latter's fiftieth anniversary. The symposium was held in Nijmegen, Netherlands, on 2-3 October 1997. We wish to thank the organizers in Nijmegen for their generous hospitality. The complete proceedings of the symposium will be published as Erik Jan Zürcher (ed.), Conscription in the Middle East (London, forthcoming).

2. There is a sizeable literature on conscription by military historians. It is, however, devoted almost exclusively to North America and Europe. Martin Anderson, Conscription. A Select and Annotated Bibliography (Stanford, CA, 1976), has 413 pages of entries, of which 20 are devoted to countries other than the US and the UK. The countries dealt with under "other foreign countries" are exclusively European or British Empire dominions. 
tally, contributing to the struggle against orientalism and its essentialist division of the world into "civilizations". ${ }^{3}$

A useful way of addressing this problem is by making use of the model proposed by Charles Tilly regarding state-building through war and state monopolization of violence. ${ }^{4}$ This implies a continuous rejuvenation of the state, including its armed forces, not simply or solely as a reaction to outside threats, but as a response to continuous changes in the availability of resources.

In the Tilly model, the tax-raising potential of a state is essential for the choice of a particular recruitment system and consequently for the possibilities of resistance. Thus in the following we shall make a distinction between the situations where taxation is not an option and those where it is, especially from the towns. In the latter case, a division of labour may occur between towns with essentially defensive militias and the much more offensive army of the state. With the help of the money raised through taxation, the state basically has a choice of three strategies: recruitment of unfree men (subjects, subjugated or purchased) who may or may not be paid; recruitment in exchange for wages on the national or international labour market; and recruitment of free subjects, who are fed and clothed, but not paid anything like a normal wage. In this last-named strategy, the free subjects may be volunteers or they may be conscripts - in which case their freedom is obviously severely limited.

We will now attempt a brief overview, a catalogue, of forms of recruitment employed in the Islamic Middle East, set against the background of developments in Europe in the early modern and modern period.

Taking as point of departure the ability of the state to raise taxes for military purposes, we may discern four major types of recruitment of men for the army and navy in the Middle East and Europe between the late seventeenth and early twentieth century: feudal recruitment, unfree recruitment, recruitment on the labour market and conscription.

\section{FEUDAL MILITARY MOBILIZATION}

Feudal military mobilization is based primarily on the non-monetary relation between the state (or king or sultan) and feudal lords or tribal chiefs. In return for administrative autonomy, land or property rights or tax

\footnotetext{
3. An inspiring example is Stephen Peter Rosen, Societies and Military Power. India and its Armies (Delhi, 1996) with his daring comparisons (for example p. 28: "Rather than arguing that Christian, Islamic, Hispanic or Hindu cultures each have specific, constant, and unique strategic outlooks, we can look at each political unit in each culture area and ask what the dominant structures are, what effects they have for the ability to generate military power, what relation the military has to society, and whether those structures and relations are changing.").

4. Charles Tilly, Coercion, Capital and European States, 990-1990 (Cambridge, MA, 1990).
} 
exemption these lords take care of the provision of soldiers. 5 The soldiers fight under their own commanders, take care of their own armour and/or horse and are mostly stationed locally. In the period under discussion we encounter this system especially in the borderlands where the settled parts of Eurasia meet the steppes and deserts.

The question whether the Ottoman Empire knew true feudalism has been debated fiercely, ${ }^{6}$ but the empire's timar system, which gave members of the cavalry (sipahis) usufruct of state lands in exchange for military service certainly had common features with the feudal system, even if the relatively strong Ottoman state, its monopoly of cereal trade and its support for the rights of peasants meant that this Ottoman "gentry" always enjoyed less freedom than its European counterpart. The freedom of action of the sipahi contingents was also curtailed because during the campaigning season they were not stationed locally, but formed part of the imperial army. The system was never employed throughout the sultan's domains. It was one of the main instruments for recruitment in the central provinces (Anatolia and the Balkans) until the late seventeenth century, by which time it had grown obsolete in two senses: as a medieval technology in the face of gunpowder armies and as a non-monetary instrument at a time when the state was desperate for cash income. ${ }^{7}$

Systems which cannot be called feudal, but which nevertheless comprised service in exchange for non-monetary rewards are those which involved armed peasants (Wehrbauern) such as the Cossacks in the Russian Empire. Some of the levends raised by the Ottoman Empire in the seventeenth and eighteenth centuries may have fallen into this category (see below).

Tribal forces of course lost their importance in the main countries of Europe very early on, unless one regards the social organization of the Cossacks as "tribal". Although the Ottoman Empire did use tribal forces, they were never central to its military organization, being auxiliaries of often

5. Because of the analytical point of view chosen, the relation between the feudal lord and his soldiers will not be discussed here; however, it will be clear that - as in the case of the relation between the state and its subjects, to be discussed below - here we also have all sorts of variations between free and unfree relations. A good example are the Hessian subsidy troops employed by inter alia the Dutch and later especially the English (e.g. in the American War of Liberation) which can be seen as capitalist hiring of mercenaries. However, within Hessen both feudal obligations and (in the second half of the eighteenth century) conscription aspects also play an important role: see Peter K. Taylor, Indentured to Liberty. Peasant Life and the Hessian Military State 1688-I8I5 (Ithaca and London, I994).

6. For a sophisticated discussion of state-peasant relations in the Ottoman Empire, see Huri Islamoğlu-Inan, State and Peasant in the Ottoman Empire. Agrarian Power Relations and Regional Economic Development in Ottoman Anatolia during the Sixteenth Century (Leiden, 1994), pp. I-2I. The bibliography gives an excellent introduction into the debate on feudalism.

7. For the transition, see Suraiya Faroqhi, "Crisis and Change", in Halil İnalcak with Donald Quataert, An Economic and Social History of the Ottoman Empire I300-I9I4 (Cambridge, 1994), pp. 413-622. 
rather doubtful value. In Persia on the other hand, as Cronin shows, tribal forces made up the backbone of the army until well into the twentieth century. When forces modelled on the Russian Cossacks were formed in the Ottoman Empire and Iran in the late nineteenth century, these were both recruited from among the tribes.

\section{UNFREE RECRUITMENT}

Unfree recruitment is based on the relation between the state and its unfree subjects, on conquest and subjugation, ${ }^{8}$ or on trade in the international slave market. According to the different origins of the unfree status we may distinguish between four types:

I Conscription of serfs in Russia. ${ }^{9}$ Under Peter the Great the Russian Empire abandoned free recruitment and drafted subjects - nearly always serfs - for no less than lifetime service. Those who had to leave their villages for ever were usually designated by the village community, the Mir. Serfs could also be condemned to military service by their feudal lords or by the courts. In 1793 the period of service was lowered to twentyfive years, but given the low life expectancy at the time this made very little difference in practice. In 1834 the term of service was reduced to a de facto period of twelve years and in I855 to ten. In I874 universal conscription on the modern pattern was introduced, an innovation only made possible by the abolition of serfdom in I86I.

2 The roughest and least regulated of the systems of unfree recruitment was that of the "press" under which able-bodied men were simply rounded up and requisitioned for army or navy. It is documented for several navies, the British and Ottoman (who used it in the Greek archipelago) among them, in the seventeenth and eighteenth centuries, but seems to have been used mainly in wartime emergencies rather than as a regular instrument of recruitment. ${ }^{\text {IO }}$

3 The system of military slaves which was widely used in the whole Middle East from the ninth until the nineteenth century. It has been said that the use of slave armies followed from needs inherent in Islamic organization, ${ }^{\text {II }}$ but if we take into account the widespread use of unfree enrol-

8. We have to keep in mind that only after the Crimean War did the Ottomans cease to enslave prisoners of war or enemy subjects: see Y.H. Erdem, Slavery in the Ottoman Empire and its Demise, I800-1909 (Basingstoke and London, 1996). However, in the nineteenth century these slaves no longer were recruited for the army or the navy.

9. Henry H. Hirschbiel, "Conscription in Russia", The Modern Encyclopedia of Russian and Soviet History, vol. VIII (Gulf Breeze, FL, I978), pp. 4-9; Peter Kolchin, Unfree Labor: American Slavery and Russian Serfdom (Cambridge, MA, 1987), pp. 42, 204, 367-368.

IO. Christopher Lloyd, The British Seaman, I200-I860: A Social Survey (London, 1968).

II. Daniel Pipes, Slave Soldiers and Islam. The Genesis of a Military System (New Haven, CT, and London, 198I), p. Ioo. 
ment outside the Muslim world, this conclusion seems doubtful. Rather, it seems that the actual form of enslavement was traditional in this part of the world, not enslavement as such. Broadly speaking, two types of slave army were employed in the Islamic world. The older one, for which the term mamluk is used, denotes well-paid professional soldiers who had been bought or captured outside the Islamic world, primarily in the Turkic steppes or in the Caucasus. The other, newer, system was that employed by the Ottomans from the late fourteenth century onwards, under which boys from Christian peasant families in the Balkans and Anatolia were enslaved and recruited for the Janissary corps (from Yeni eri - New Army). ${ }^{\mathrm{I} 2}$ In both cases the logic of the system seems to have been that people were recruited from among those furthest removed from the establishment ${ }^{13}$ (although, of course, in both cases the slave soldiers developed into a power elite themselves).

4 The use of convicts and slaves on the galleys. ${ }^{\mathrm{I}}$ This method was employed primarily on the Mediterranean galleys of all powers until well into the eighteenth century, when sailing ships had made galleys obsolete as a fighting force anyway. As is well known, in the battle of Lepanto (I57I) all contesting fleets were heavily dependent on Greek, Albanian, Bosnian and other slaves from the Balkans. ${ }^{15}$ Outside the Mediterranean, the Portuguese seem to have used slaves on their sailing ships, as occasionally did the Dutch on their East Indiamen. ${ }^{16}$

\section{RECRUITMENT ON THE LABOUR MARKET}

Recruitment through the labour market is based on the relation between the state and the (national or international) labour market. Remuneration can take the form of wages or prize-money, booty or less directly material

I2. Ibid.; Stephen Peter Rosen, Societies and Military Power. India and its Armies (Delhi, I996), pp. II4-II5, II9-I23; İsmail Hakkı Uzunçarşılı, Kapıkulu Ocakları (Ankara, 1943-1944), 2 vols.

13. This is the reason why the Ottomans rejected the possibility of recruiting the children of townspeople.

I4. See André Zysberg, Les galériens. Vies et destins de 6000 forcats sur les galères de France I680I748 (Paris, I987); Frederick C. Lane, Venice. A Maritime Republic (Baltimore, 1973), pp. 364-379, 4I4-4I5.

I5. In the eighteenth century galleys vanished from the Mediterranean but became popular in the Baltic. There the Russians deployed serfs under their new conscription system, but other nations used free oarsmen.

I6. Jan Lucassen, "The International Maritime Labour Market: Sixteenth-Nineteenth Centuries", in Paul van Royen, Jaap R. Bruijn and Jan Lucassen (eds), "Those Emblems of Hell"? European Sailors and the Maritime Labour Market, I570-1870 (St John's, Newfoundland, I997), pp. II-23; $\mathrm{K}$. van der Tempel, "'Wij hebben amok in ons schip': Aziaten in opstand tijdens drie terugreizen op het einde van de achttiende eeuw”, in J.R. Bruijn and E.S. van Eyck van Heslinga (eds), Muiterij. Oproer en berechting op schepen van de VOC (Haarlem, I980), pp. I23-I47. 
gains such as secular or religious honour. ${ }^{17}$ Two ways of hiring soldiers are possible: either individual and direct recruitment or collective and indirect recruitment. As in all crafts and professions, some regions or ethnic communities can specialize in this trade. A good example is provided by the individual recruitment of mercenaries as it was employed by many great powers in Europe from the Middle Ages onwards. The recruits could be local, but especially in times of war they could come from quite far away. In the early modern period the Venetians, the Spanish, the French, the Dutch and - after the Glorious Revolution - also the English used mercenaries. Irish, Scots, Swiss and inhabitants of some German states like Hesse, Hanover and Brunswick specialized in this trade. Their religious conviction could influence their attractiveness to foreign employers. ${ }^{18}$ An international maritime labour market, also involving the navies, seems to have come into being later. In the early modern period only the Dutch Republic could really boast of having established one, to be followed only from the midnineteenth century by the Americans and then the British. Over the last century a global maritime labour market was established, but by then it had lost its significance for the navies.

In the Ottoman Empire, the most common type of recruitment on the labour market was that of the levends. These were generally young landless villagers in the pay of the state or provincial military leaders. When they were self-employed, there was often very little to distinguish them from robber bands. When its traditional core forces became less and less useful, the empire, in spite of its ideological attachment to the concept of a sharp division between an armed governing elite (askerî) and unarmed productive subjects (reaya), came to rely rather heavily on these troops. ${ }^{19}$

We can also discern certain ethnic groups which specialized in this military trade, notably Albanians and Bosnians. Whatever their legal status and mode of payment, by the eighteenth century to all intents and purposes these were hired mercenaries. A man like the Albanian Mehmed Ali Pasha, whose army is the subject of Fahmy's article, can definitely be described as a successful soldier of fortune.

17. Gregory Hanlon, "The Decline of a Provincial Military Aristocracy: Siena 1560-1740”, Past and Present, I55 (May 1997), pp. 64-108.

18. For Hessians see Taylor, Indentured to Liberty; for Scots see T.C. Smout, N.C. Landsman and T.M. Devine, "Scottish Emigration in the Seventeenth and Eighteenth Centuries", in Nicholas Canny (ed.), Europeans on the Move. Studies on European Migration, I500-I80o (Oxford, 1994), pp. 76-II2; Thomas C. Smout, "Scots and Emigrants in Europe, I400-I700", in Simonetta Cavaciocchi (ed.), Le Migrazioni in Europa secc. XIII-XVIII (Prato, 1994), pp. 659-669 and Dmitry G. Fedosov, "Russia's Scottish Clans", in ibid., pp. 86I-866; for Irish see Robert A. Stradling, "Military Recruitment and Movement as a Form of Migration: Spain and its Irish Mercenaries, 1598I665", in ibid., pp. 477-490 and L.M. Cullen, "The Irish Diaspora of the Seventeenth and Eighteenth Centuries", in Canny, Europeans on the Move, pp. II3-I49.

19. Johannes Hendrikus Kramers [and William Griswold], "Levend", Encyclopaedia of Islam, vol. VIII (Leiden, 1986), pp. 728-729. 
Collective recruitment with the help of intermediaries was also common. It is not always possible to make a clear distinction between this form and individual recruitment, but in the cases of subsidy regiments and privateers, the form is mostly collective. The employment of privateers - essentially pirates sailing for booty under legal sanction by a state - continued until the 1850 o both in the Christian and in the Muslim world. ${ }^{20}$ In the Ottoman case, the best-known example is that of the corsairs from the Barbary coast (Algiers, Tunis, Tripolitania and Cyrenaica), who in their turn employed free locals (Arabs and Turks) and slaves (including captured Christians). Outside Ottoman jurisdiction, the privateers of Salé and Tangiers earned their reputation as merciless hunters of the sea. ${ }^{21} \mathrm{~A}$ well-known example from the other side is that of the Maltese. The equivalent of these naval mercenaries on land were the "Uskoks" on the Ottoman-Austrian border, who could fight on both sides. ${ }^{22}$ The Ottomans also used locally hired mercenaries on the Danube.

Bedouin tribal forces were nearly always free actors, who were paid collectively for their services (although it has to be said that they were more often paid for not attacking the Ottomans' own caravan trade, rather than for fighting in the sultan's cause). ${ }^{23}$

As all these examples make clear, different systems nearly always coexisted within one state. There is no clear-cut development from a "primitive" to a "modern" system through well-established intermediate stages.

\section{CONSCRIPTION - UNIVERSAL AND OTHERWISE}

We now come to our main topic: recruitment through conscription. Although essentially a modern system with its roots in the French revolutionary period, the phenomenon has predecessors in Europe. In order to understand the novelty of the system, we have first of all to make a distinction between indirect and direct conscription.

\section{Indirect conscription}

Before national, centralized and theoretically universal conscription was introduced, we can already discern older systems of indirect conscription which share some of its characteristics. Peter the Great's conscript army was

20. Janice E. Thomson, Mercenaries, Pirates and Sovereigns. State-Building and Extraterritorial Violence in Early Modern Europe (Princeton, NJ, 1994).

2I. Geoffery Fisher, Barbary Legend. War, Trade and Piracy in North Africa, I4I5-I830 (Oxford, I957).

22. Catherine Wendy Bracewell, The Uskoks of Senj. Piracy, Banditry and the Holy War in the Sixteenth-Century Adriatic (Ithaca and London, 1992).

23. Suraiya Faroqhi, Pilgrims and Sultans. The Hajj under the Ottomans I5I7-I683 (London, I994), pp. 54-73. 
recruited in an indirect manner in that the great landowners were charged with filling their complement of recruits and largely left free in the choice of their actual conscripts. The actual selection was then mostly left to the village elders in the mir. The bunichah system introduced in Persia in the I840s (and described by Cronin) was also of this type.

In large parts of Europe, from the Middle Ages onwards, we see local militia systems, mostly organized separately in the towns and in the countryside. In medieval and early modern European towns craft guilds often provided a number of civic tasks such as fire fighting and local defence. In the Dutch Republic more professional militias (schutterijen) took over the task of defence, while in Venice craft guilds could even have offensive duties when they had to take their share in manning the galleys. ${ }^{24}$ The countryside also often had militias for self-defence. ${ }^{25}$ Villagers were often loosely organized and ill-trained, but the aptitudes which enabled them to survive in harsh circumstances often gave them a natural ability as soldiers, especially in remote and mountainous areas.

In the pre-modern Middle East towns had never achieved the corporate identity and autonomy which became the norm in late medieval Europe. Middle Eastern states did not recognize the rights of citizens (an alien concept in itself) to arm and defend themselves. Nevertheless something approaching a town militia came into being when the Janissary army lost its original standing and professional character in the late sixteenth century. In the seventeenth and eighteenth centuries the corps developed close links with the craft guilds and in effect became a part-time militia of shopowners, ready to defend their interests against encroachments on the part of the state, but almost useless as an instrument of that state in warfare. Indeed, finding alternatives to the Janissaries became a prime concern of the Ottoman government.

In spite of the theoretical monopolization of violence on the part of the state, the Ottoman (but also the Persian) countryside was quite heavily armed. The Ottoman state made use of this state of affairs when it began to recruit large numbers of young armed peasants as levends in the seventeenth century and disarming the countryside was as much a cause for resistance in the nineteenth century as the introduction of universal conscription.

\section{Direct conscription}

These systems depend on the relation between the state and its individual free subjects. In principle, remuneration only exists in the form of subsistence, although the state is responsible for clothing and equipment. If pay-

24. Lane, Venice.

25. See Taylor, Indentured to Liberty. 
ment occurs, it is additional (e.g. in the shape of a sign-up premium) and very low. Early examples of conscription (other than that of Peter the Great, which, as we have seen, can be termed "indirect") can be found, for instance in the conscription navale introduced by Colbert in the French navy to replace the earlier press-gangs and in Hesse and Hanover, but the breakthrough of conscription came in the context of the French Revolution.

The army of the French Republic at first was a motley collection of remnants of the royal army of the Bourbons, militias and volunteers, but this clearly could not fulfil the military requirements of revolutionary France when it was attacked on all sides. The famous convention decree of August I793 introduced in all of France the individual obligation (and right) of every French citizen to be a soldier. In doing so, it of course brought with it a need to define clearly who was a French citizen and who was not. At least in theory, the point of departure was the armement général du peuple. This first levée en masse of 1793 , through which an army of 400,000 was raised, did not really constitute the start of conscription in practice, however. The obligation to serve was a general one, but by and large those who served were volunteers. Real conscription was introduced five years later, when revolutionary fervour had worn off and the number of volunteers had dwindled, under the Loi Jourdan of September 1798. The system was exploited to the limits of its possibilities - and beyond - by Napoleon Bonaparte. $^{26}$

After the restoration, most countries, including France, largely abandoned universal conscription in exchange for a standing army of professionals, reinforced with long-term conscripts from the poorest sections of the population (precisely at the time when the French officers who figure in Fahmy's article introduced the conscription system in the Egyptian army). In France, the middle class was almost completely exempt under a system which allowed those who were drafted to send, or pay for, a replacement. This, in fact, is a universal feature of early conscription systems in countries as far apart as France and Russia and it faced the state and its ruling elite with the dilemma that for its survival it depended on an army recruited from among those who had the least stake in society and might be politically least reliable (in addition to being the worst educated). This problem became more acute with the rise of socialism in the later nineteenth century. As Zürcher's article shows, in the Ottoman Empire exemptions were a particularly intractable problem, as - at least until 1909 - Christians and Jews were not expected to serve and the burden fell on the Muslim population alone.

Conscription systems such as the French, which relied on relatively long periods of service (eight years and over) resulted in relatively large and

26. See Alan Forrest, Conscripts and Deserters. The Army and French Society during the Revolution and Empire (Oxford, 1989). 
expensive standing armies, which, however, could not be strengthened in wartime by calling up a trained reserve. It also kept a large number of males away from the labour market during their most productive years. This problem was solved in Prussia by the army reforms which were introduced gradually after the defeat at Jena in 1806 and which resulted in the Law on Conscription of September I8I4. Under this law, the male population was required to serve between one and three years in the regular frontline army, followed by service in the first and second class reserve (Landwehr) and finally in the Landsturm militia, which would only be activated in case of an enemy invasion. This hugely influential model combined the advantages of a relatively small standing army manned largely by professionals and volunteers with the availability of a large pool of trained reserves who could be called up in case of war. For the proper working of the system the linkages between the regular army and the reserve were essential. This later led to the dissolution of the separate structure of the reserve, with reservists filling out regular units rather than serving in their own, a practice followed by the Ottomans on the eve of the First World War. ${ }^{27}$ The Prussian system proved its effectiveness in the wars of I866 and I870 and as a result all European countries, except the United Kingdom, adopted "universal" compulsory military service as a defensive measure even in peacetime. In the Ottoman Empire the conscription system introduced in 1844 was modelled on the Prussian example and after 1870 Prussian/German influence grew markedly. Eventually, the system became well-nigh universal. Even those countries where there was great reluctance to employ it, like the United States and Britain succumbed. The US used the system temporarily during the Civil War and in the great wars of the twentieth century, finally abandoning "the draft" towards the end of the Vietnam War in 1969. Britain adopted conscription when Kitchener's army ran short of volunteers in 1916 and even reintroduced "national service" after the Second World War, only reverting to a professional army in 1963.

Military considerations apart, conscript armies have been seen as prime instruments for nation-building. This was already recognized in the nineteenth century, but it became especially important in the new nation states created during the break-up of empires after the First World War and during the decolonization process after the Second World War. Cronin points to the importance of this factor in the Middle East at the start of her article.

There are a number of prerequisites for the successful introduction of a conscript army. First of all, a reliable census has to be in place to determine

27. Heinz Stübig, "Die Wehrverfassung Preussens in der Reformzeit. Wehrpflicht im Spannungsfeld von Restauration und Revolution 1815-1860", in Roland G. Foerster (ed.), Die Wehrpflicht. Entstehung, Erscheinungsformen und politisch-militärische Wirkung (Munich, 1994), pp. 39-53; Stig Förster, "Militär und staatsbürgerliche Partizipation. Die allgemeine Wehrpflicht im Deutschen Kaiserreich I87I-I9I4", in ibid., pp. 55-70. 
where the potential manpower can be found. This required a sizeable growth in the state bureaucracy even outside the purely military apparatus. Then an efficient apparatus for the actual recruitment and, in almost every case, efficient sanctions (such as cantonnement of troops in houses of those who refuse to turn up, or hostage-taking of family members) to combat desertion have to be put in place. ${ }^{28}$ In most cases service was determined by the drawing of lots, in which case a system of lottery has to be introduced and executed. The troops have to be moved, fed, clothed and armed in much larger numbers than before, which presupposes a certain degree of economic efficiency, or even industrialization, which was completely nonexistent in the Ottoman Empire or Persia. Raw recruits from the countryside have to be educated and trained so as not to lower the efficiency of the standing professional army too much - quantity should not endanger quality. Some of the fiercest resistance to general conscription has in fact come from within the professional army for this very reason.

The use of an army of conscripts also had far-reaching consequences for the way war was waged and the way it was presented to the population. As war now involved the whole population, mobilizing and motivating that population through the use of propaganda acquired an altogether novel importance (evolving into the concept of the "Home Front" in the First World War). Likewise, breaking the enemy's will (and that is, after all, according to Clausewitz the ultimate goal of any warfare) now also involved breaking the will to resist of the enemy population, not only of the army in the field. The concept of a "nation in arms" almost inevitably led to different behaviour of the army vis-à-vis the enemy population as was demonstrated during the Franco-Prussian War of I870. Guerrilla warfare had its origins in the aftermath of the French Revolution (when the Spanish first used the term for their popular resistance against Napoleon's occupying forces) and the use of franc-tireurs by the French in the 1870 war stood in this tradition. It blurred the distinction between soldiers and civilians even further and led to hostage-taking and random shootings by the Germans which presaged the tragedies of Oradour and My-Lai in the twentieth century.

The reliability of the conscript armies was always a worry in the minds of the General Staff, though in the event even the enormous hordes of conscripts which were thrown into battle in the First World War proved remarkably resilient. Only after three years of almost incredibly ferocious fighting did the first major signs of dissent appear (the famous mutiny of May 1917 in the French army), but even then it was fairly easily put down. But in a sense the generals were right, of course: the conscripts were essentially civilians in uniform and by sheer weight of numbers they tended to

28. See for examples in the Netherlands: Alex Barten and Frans Kraan, Stelligen Onwil. Dienstweigering tijdens de Belgische Opstand (Amsterdam, 1996). 
determine the atmosphere in the armies more and more. In the long run this necessitated a different style of leadership, at least in those countries where the population became more literate, wealthy and mobile. The American armies in both world wars and the contemporary NATO forces are examples of this trend. In exchange for the willingness of the populations to fight and to keep on fighting, hard-pressed governments had to make promises of social justice ("A land fit for heroes to live in"). In the aftermath both of the First World War and the Second World War these promises were at least partly fulfilled, leading to the welfare state after 1945 .

\section{THE OPTIONS OF THE RECRUIT}

Turning from the state and its concerns to those at the receiving end of its policies, we should now try to catalogue the possible reactions to military recruitment, to see which specific types of resistance may be expected in which situations.

The most outspoken resistance may be expected where new forms of recruitment are introduced, where the rules are changed dramatically (as in the case of the introduction of conscription) or when circumstances change dramatically, e.g. when war breaks out or when wars are lost.

The choice whether to resist at all and the choice of a particular form of resistance depend essentially on two things: the assessment of the balance between advantages and disadvantages of military service and the available resources and repertoires of action. Both factors cannot be analysed simply as a result of individual calculations on the part of the recruit. As his immediate relatives are severely affected as well, the resistance should really be analysed in the framework of household strategies. The way resistance will express itself is heavily dependent on the repertoire of action that is available, both within the community of origin and in the army.

What may be an advantage to one young man in his prime, may be a disadvantage to another. Where the prospective mercenary, his relatives and his future bride will see the army as a (rare) job opportunity or a possibility to enhance their status, most conscripts and their families will blame the army for loss of income or worse. The disadvantage will be all the greater if service in the army involves immediate risks such as undernourishment, disease, mistreatment (spectacular in the case of Mehmed Ali's army) or danger. Obviously all of these aggravating circumstances count more in times of war than in peacetime. The longer the service, the worse the prospects for the recruit of ever returning to his village. It is telling that in Russian villages, the departure of the recruits was sometimes "celebrated" with a funeral ceremony. In the Ottoman Empire, a whole body of military songs exists, which depicts conscription as a death sentence. ${ }^{29}$

29. Erik Jan Zürcher, "Little Mehmet in the Desert. The Ottoman Soldier's Experience", in Hugh Cecil and Peter Liddle (eds), Facing Armageddon. The First World War Experienced (London, I996), pp. 230-24I. 
The available resources of avoidance and resistance are clearly linked to the way in which recruitment is organized. If we restrict ourselves to conscription only, we have to take into consideration the degree to which the state was able to muster the bureaucratic force to execute the system effectively. As noted earlier, this involved registration, medical examinations, regulations about exemptions, the drawing of lots, the actual enrolment, transport and drilling. Obviously, making use of each of these stages in the process to avoid recruitment is far easier in a state, like the Ottoman in the nineteenth and the Persian in the early twentieth century, where the bureaucracy was still being created than in one of the established bureaucratic states of Europe.

Opportunities are not the only determining factor, however. Which forms of resistance are used is "path-dependent", in other words it depends on the existing traditions of avoidance and resistance in the army and navy and in society at large.

Resistance can take on many forms. The recruit can try to avoid recruitment by going into hiding. In Anatolia and the Balkans, "leaving for the mountains" to escape the demands of the state was an age-old tradition. From the seventeenth century onwards, the lowland tracts close to the main roads had become a wasteland and communities had withdrawn into the mountains. Brigandage was very widespread even in the early twentieth century. Another strategy, available to those with enough means, was leaving the country temporarily or for good (or taking on a different nationality as many Ottoman Greeks and Armenians did after 1909); an Ottoman Muslim recruit could convert to Christianity or - the opposite solution - perform the hajj. He could mutilate himself in order to be sent home (a strategy employed in all armies, but apparently very widespread in Mehmed Ali's Egyptian army).

Of course, the soldier can try to desert, either on the way to the front or towards the enemy. The first seems to have been very widespread in the Ottoman army, both because of its lax controls and because it was socially quite acceptable to the villagers. The second was rare, at least if the enemy was Christian.

Soldiers contemplating resistance of any kind of course have to take into account the risks and the penalty that may have to be paid. These penalties were always more severe than in civilian life because soldiers are dealt with under martial, that is to say criminal, law. ${ }^{30}$

Strategies like avoidance or desertion are largely individual but they do require the support of household, family or village. If desertion is not an option, the recruit can strike or refuse to carry out orders, and, finally, he can rebel, that is to say join a mutiny. All of these are collective actions which

30. Outside the Anglo-Saxon world, where breach of contract still fell under criminal law until very late (in Britain until I875-I877), in most European countries labour contracts (except for sailors) fell under civil law. This is an important distinction between military and civilian jobs. 
require organization. As the risks of overt resistance are great, these ultimate means will be avoided as long as possible. If practised these will tend to take the form of peaceful demonstrations and petitions, rather than open revolt. In these, too, families can play a part. As they are not under the constraints of military discipline, they can often protest more easily than the men themselves. In the case of a Dutch naval mutiny in I779, the wives of the seamen sent an anonymous letter to the admiralty board reminding its members that their wearing of expensive wigs was made possible only because they - the wives - had nothing but cabbage stalks to eat ("want voor ons geld soo draegen de heeren pruijke en wij moeten eete koolstruijke"). ${ }^{31}$ If an open revolt comes to pass, the participants will act as one unit, avoiding individual liability. A clear example from naval mutinies is the so-called "Round Robin". ${ }^{32}$ This is a declaration on paper which was described in 1716 as follows:

They take a large Sheet of Paper, and strike two Circles, one a good distance without the other; in the inner Circle, they will write what they have a mind to have done; and between the two Circular Lines, they write their Names, in and out, against the Circles; beginning like the four Cardinal points of the Compass, right opposite to each other, and so continue till the Paper is filled; which appears in a Circle, and no one can be said to be first, so that they all are equally guilty: Which I believe to be contrived to keep 'em all firm to their purpose, when once they have signed it; and if discovered, no one can be excused, by saying, he was the last that signed it, and he had not done it without great Persuasion.

Different armies have had to face different forms of resistance. In France, for example, the General Staff was convinced that the entire army was "rotten" when desertions increased forty times from around 500 in 1914 to $2 \mathrm{I}, 000$ in $1917,{ }^{33}$ but the much smaller Ottoman army by 1918 had half a million deserters. On the other hand, mutinies were almost unheard of in the Ottoman army of the First World War, even when the soldiers were barefoot and starving. ${ }^{34}$ Clearly, here the "path", the pre-existing strategy of which the soldiers could avail themselves, was missing. Mutinies had been a common phenomenon in the pre-modern Ottoman army. Many coups d'etat had started with the Janissaries turning over their soup kettles. But the conscript armies of Egypt and the Ottoman Empire were armies of peasants who came from a very different tradition from that of the town-

3I. Jaap R. Bruijn, The Dutch Navy of the Seventeenth and Eighteenth Centuries (Columbia, SC, 1993), p. 206.

32. Marcus Rediker, Between the Devil and the Deep Blue Sea. Merchant Seamen, Pirates, and the Anglo-American Maritime World, I700-1750 (Cambridge, 1987), p. 234; D.L.M. Weijers, "Dappere waterleeuwen versus schelmen': een muiterij in Perzische wateren, I733”, in Bruijn and van Eyck van Heslinga, Muiterij, pp. 44-57.

33. Leonard Smith, "The French High Command and the Mutinies of Spring 1917", in Cecil and Liddle, Facing Armageddon, pp. 79-92.

34. Erik Jan Zürcher, "Between Death and Desertion. The Experience of the Ottoman Soldier in World War I", Turcica, 28 (1996), pp. 235-258. 
and city-based Janissaries with their strong esprit de corps. Strikes were not unknown in the empire. Closing down the bazar was a very traditional means of protest (it was still practised during the Iranian revolution and the Intifada) and industrial strikes had proliferated after 1908, but they were limited to the few centres (Salonica, Istanbul, Izmir, Bursa) where a small industrial workforce had come into being in the late nineteenth century. ${ }^{35}$ Again, both traditions were alien to the village population which made up the bulk of the army.

Because of the enormous difficulties and penalties involved in all forms of resistance, here, too, we have to abstain from a one-sided analysis of recruits as individuals, detached from their communities of origin. These communities are important, not only in weighing advantages against disadvantages (although, admittedly, in the case of conscription the disadvantages far outweighed any advantages), but also in the acts of avoidance and resistance. Emigration, flight, hiding, self-mutilation, bribery - all of these can hardly be practised without the help of one's relatives. Because the actual or future household is at stake, all these acts can be interpreted as household strategies.

Anxiety about the survival of the families they left behind was also often a morale-sapping issue for the conscripts. The detailed provisions made by the Ottoman government for "families left without breadwinner" (muinsiz aile) show the official concerns on this point. At least this was a more benign sort of attention than that displayed by the Russian government, which in the I830s launched a propaganda campaign praising mothers who turned in their fugitive sons and awarding informers a special silver medal inscribed "for diligence". ${ }^{36}$

The following three essays involve a journey through time and space. Khaled Fahmy presents the story of the army of Mehmed Ali Pasha of Egypt, who pioneered conscription in the Middle East. Erik Jan Zürcher describes how the Ottoman Empire organized its recruiting system when it answered the Pasha's challenge. Stephanie Cronin takes us further, to Iran where conscription only became an issue in the early twentieth century, causing widespread resistance.

It is hoped that these studies combined will allow the reader to see that both where conscription as part of the formation of modern states is concerned and where the focus is on the repertoire of resistance of individuals, households and communities, there are striking similarities not only between the different countries of the Middle East but also between the Middle East and Europe. The logic of state formation and the reactions it encounters clearly transcend boundaries of civilizations.

35. See Donald Quataert, Social Disintegration and Popular Resistance in the Ottoman Empire, I88I-I908 (New York, I983).

36. Kolchin, Unfree Labor, pp. 282-283. 